\title{
LAND USE/ COVER (LULC) MAPPING IN BRAZILIAN CERRADO USING NEURAL NETWORK WITH SENTINEL-2 DATA
}

\author{
Janailson Francisco da Silva ${ }^{1 *}$, Rejane Ennes Cicerelli² ${ }^{2}$ Tati Almeida², Marina Rolim Bilich Neumann ${ }^{3}$, \\ André Luiz Farias de Souza ${ }^{4}$ \\ 1* Universidade de Brasília, Instituto de Geociências, Especialização em Geoprocessamento, Brasília, DF, Brasil - janailson.s@ gmail.com \\ ${ }^{2}$ Universidade de Brasília, Programa de Pós-graduação em Geociências Aplicadas e Geodinâmica, Brasília, DF, Brasil - \\ rejaneig;tati_almeida@unb.br \\ ${ }^{3}$ Universidade de Brasília, Faculdade de Agronomia e Medicina Veterinária, Agronomia, Brasília, DF, Brasil - marinabilich@unb.br \\ ${ }^{4}$ Secretaria de Meio Ambiente do Distrito Federal, Brasília, DF, Brasil - andrelfsouza@gmail.com
}

Received for publication: 25/09/2018 - Accepted for publication: 23/04/2020

\begin{abstract}
Resumo
Os satélites Sentinel-2A e 2B compõem a missão imageadora multiespectral para observação da Terra. Esses satélites possuem características promissoras para o mapeamento automático, podendo seus dados serem aplicados no mapeamento do uso e cobertura do solo. Para esse fim, as redes neurais têm demonstrado bons resultados em tarefas de reconhecimento de padrões em imagens orbitais. Nesse sentido, o estudo objetivou avaliar o uso de imagem do Sentinel 2 (ESA) para mapeamento do uso e ocupação do solo no Bioma Cerrado, por meio da aplicação da metodologia de rede neural artificial (RNA). Dentre as classes de uso e cobertura examinadas, foram selecionadas 8 classes, sendo 4 naturais (corpos d'água, savana, formação florestal e campestre) e 4 antrópicas (Pastagem, área urbana, silvicultura, e cultura temporária). A acurácia temática calculada por meio do índice Kappa para RNA foi de $77 \%$ e se mostrou superior se comparado ao classificador MaxVer. Assim, a imagem do Sentinel-2, aliada ao uso de uma rede neural, mostrou-se um bom mecanismo para execução desse tipo de mapeamento.

Palavras-chave: Sensoriamento Remoto, Técnicas de Classificação supervisionada, Classes de uso e cobertura da terra.
\end{abstract}

\begin{abstract}
The Sentinel-2A and 2B satellites form a multispectral imaging mission for Earth observation. They have promising characteristics for the study of soils and vegetation cover, and their data can be applied for land use/cover (LULC) mapping. To this end, neural networks have shown good results in pattern recognition tasks in orbital images. In this sense, the study aimed to evaluate the use of Sentinel 2 (ESA) image for LULC mapping in the Cerrado Biome, through the application of artificial neural network methodology. Among the classes of use and occupation examined, 8 classes were selected, 4 of which were natural (water bodies, savanna, forest and field formation) and 4 anthropic (Pasture, Urban areas, Silviculture and Seasonal Crop). The classification system by artificial neural network (ANN) was considered successful, with thematic accuracy (Kappa coefficient) of 0.77. Although there are still some thematic confusions during the classification process, the classification results were considered superior when compared to the MaxVer classifier. The Sentinel-2 image, together with the use of a neural network, was shown a good input for carrying out this type of mapping.

Keywords: Remote Sensing, Supervised Classification Techniques, LULC classes.
\end{abstract}

\section{INTRODUCTION}

The land use/cover mapping is a useful instrument in the knowledge and updating of the use and cover of space, playing a crucial role in the planning and the orientation of decision making (SANO et al., 2019a; DENG et al., 2019). The application of this technique permits quantify transformations caused by natural or man-made processes. The Cerrado has been at the center of agribusiness expansions, mainly because of its high production of grain for exportation (SANO et al., 2019b). Because of the biodiversity richness and high levels of endemism, Cerrado is considered one of world's hotspot for biodiversity conservation and occupies approximately $23 \%$ of the Brazilian territory (SANO et al., 2019b). The understanding of the dynamics of occupations is essential for the definition of actions and policies aimed at preservation and the development of sustainable strategies in this biome.

The use of satellite images, mainly of the Landsat series, for LULC mapping in the Cerrado has been widely used in the last decades (GRANDE et al., 2016; GRECCHI et al., 2014). Landsat-8 and Sentinel-2A are the most advanced satellites with freely available data for remote sensing applications for good temporal

FLORESTA, Curitiba, PR, v. 50, n. 3, p. 1430 - 1438, jul/set 2020.

Silva, J. F. et.al.

ISSN eletrônico 1982-4688

DOI: 10.5380/rf.v50 i3. 59747 
resolution frequency. for a long time the Landsat system has been tested on some papers for Cerrado (GRANDE et al., 2016; SCHWIEDER et al., 2016; SANO et al., 2019), however, little is known about the Sentinel system performance. The Sentinel-2A satellite is equipped with multispectral instruments (MSI) capable of acquiring information of 12 bands in different spatial resolutions (10m, 20m and 60m) (ESA, 2015; DU et al. 2016).

Compared to Landsat 8, Sentinel-2A has more refined properties, such as narrower bandwidth, shorter revision time, and better spatial resolution. In addition, it provides more detail on the NIR and SWIR tracks, which is useful for agriculture, forest and natural resource monitoring, and disaster management. As the number of bands and the spatial and temporal resolution determine the quality of the multispectral image; consequently, the Sentinel-2A satellite has characteristics that indicate that it is more suitable for remote sensing applications (MANDANICI; BITELLI, 2016). With a high temporal and spectral resolution, Sentinel-2 shows advantages in continuous and intensive surface monitoring (DU et al. 2016).

Therefore, studies using this sensor are important to recognize its true capacity and potential, especially in complex environments such as the Cerrado. In the Cerrado, the natural heterogeneity forms a spatial gradient between savanna and forest phytophysiognomies. Consequently, the separability is not trivial, since the different formations are not categorically distinct spatially. In addition, the Cerrado has classes with similar spectral responses (SANO et al., 2019).

Allied to this, there is no one ideal classification of LULC, and it is unlikely that one could ever be developed. There are different perspectives in the classification process, and the process itself tends to be subjective, even when an objective numerical approach is used (STEHMAN, 1997). These techniques were widely studied, but with different performances based on configuration of classification system. In the supervised process, the spectral space, obtained by a sensor, with land cover classes identified by an analyst, is associated and provide training areas for the parameters of a classifier, such as the Maximum Likelihood classifier. This algorithm calculates the probability of a given pixel belonging to one of the classes, considering as Normal or Gaussian the distribution of the training sample, described by the mean vector and by the covariance matrix of the pixel (RICHARDS, 2013).

Artificial neural networks (ANNs) present more accurate results than the classification methods based on classical statistical parameters (HEYDARI et al., 2019). Benediktsson et al. (1990), Arruda et al. (2013) and Heydari et al., 2019, indicate that ANNs are more efficient in the tasks of pattern recognition in orbital images because, initially, they do not assume any statistical distribution about the classes, unlike the classifiers based on parametric statistics, which assumes a known distribution. Venkatesh and Raja (2003) used artificial neural networks to classify satellite images. The classes of coverage identified were: forests, agriculture, mountains, roads, rocky terrain and bodies of water.

ANNs have been successfully applied in the areas of image processing and pattern recognition. An ANN uses nonlinear elements (called neurons) organized as networks, in a manner analogous to the belief that neurons are interconnected in the brain. Several works using ANNs as classifiers (ARRUDA et al. 2013; HEYDARI et al. 2019). These classifiers made use of a multilayer network of perceptrons (MLP) to solve the classification problem.

Previous studies of Cerrado LULC change imply spatial homogeneity, report widely varying rates of land conversion, use ambiguous LULC categories, and generally do not attempt to validate results. LULC studies in Brazil for large areas and periods are based on traditional techniques, such as Maximum Likelihood (MLC), Spectral Angle Mapper (SAM) or ISODATA algorithm (BRANNSTROM et al., 2008; SANO et al., 2009). More recently there are research records using other automatic classification techniques in the cerrado (SOUZA MENDES, 2019; SCHWIEDER et al., 2016). Therefore to ensure the results' effectiveness it is necessary to carry out complementary studies that focus on analyzing new data and automatic classifications considering the characteristics to each biome.

Thus, this work aims to evaluate the potential of the use of Sentinel-2A satellite images, using artificial neural networks (Back Propagation training algorithm) in the mapping of LULC in the Cerrado Biome area.

\section{MATERIALS AND METHODS}

In order to test the potential of both satellite images and the classifier, the selected study area has a great variability of occupations, such as preserved areas of phytophysiognomies typical of the Cerrado Biome, areas with dry and irrigated agricultural production, as well as pastures and urban areas. The study area covers the eastern portion of the Federal District and borders the states of Goiás and Minas Gerais (Figure 1).

The image used in the work was obtained by the Sentinel-2A satellite using the optical sensor MSI Multispectral Instrument on 08 August 2016. This satellite, manufactured by the European Space Agency (ESA,

FLORESTA, Curitiba, PR, v. 50, n. 3, p. 1430 - 1438, jul/set 2020.

Silva, J. F. et.al.

ISSN eletrônico 1982-4688

DOI: $10.5380 /$ rf.v50 i3. 59747 
(http://www.esa.int/Our_Activities/Observing_the_Earth/Copernicus/Sentinel-2), which presents 12 spectral bands with spatial resolutions between 10 and 60m (ESA, 2015).

The processed image was acquired free of charge by the COPERNICUS system and has an L1C processing level (top-of-the-atmosphere orthorectified image). The pre-processing was performed to obtain the L2A level, where the values refer to the BOA (base of atmosphere) using the Sen2cor tool, Snap software module, developed by the European Space Agency itself. Subsequently, some bands were resampled to $20 \mathrm{~m}$ for joint use in the classification.

\section{Definition of classes of use and occupation: training samples}

The nomenclature of LULC mapping was defined based on IBGE methodology (2013) for anthropic areas and Ribeiro and Walter (2008) for areas with natural cover. The IBGE methodology (2013) is divided into 3 levels, with the detail increasing at each level, with scales up to 1: 100,000. At level 1 are the classes that represent the purely land occupation features, level 2 indicate classes of land use activities, not just occupation, and at level 3 predominate classes representing land use activities. To reach the degree of detail of level 3, it is necessary to include information from other sources such as Google Earth and auxiliary images.
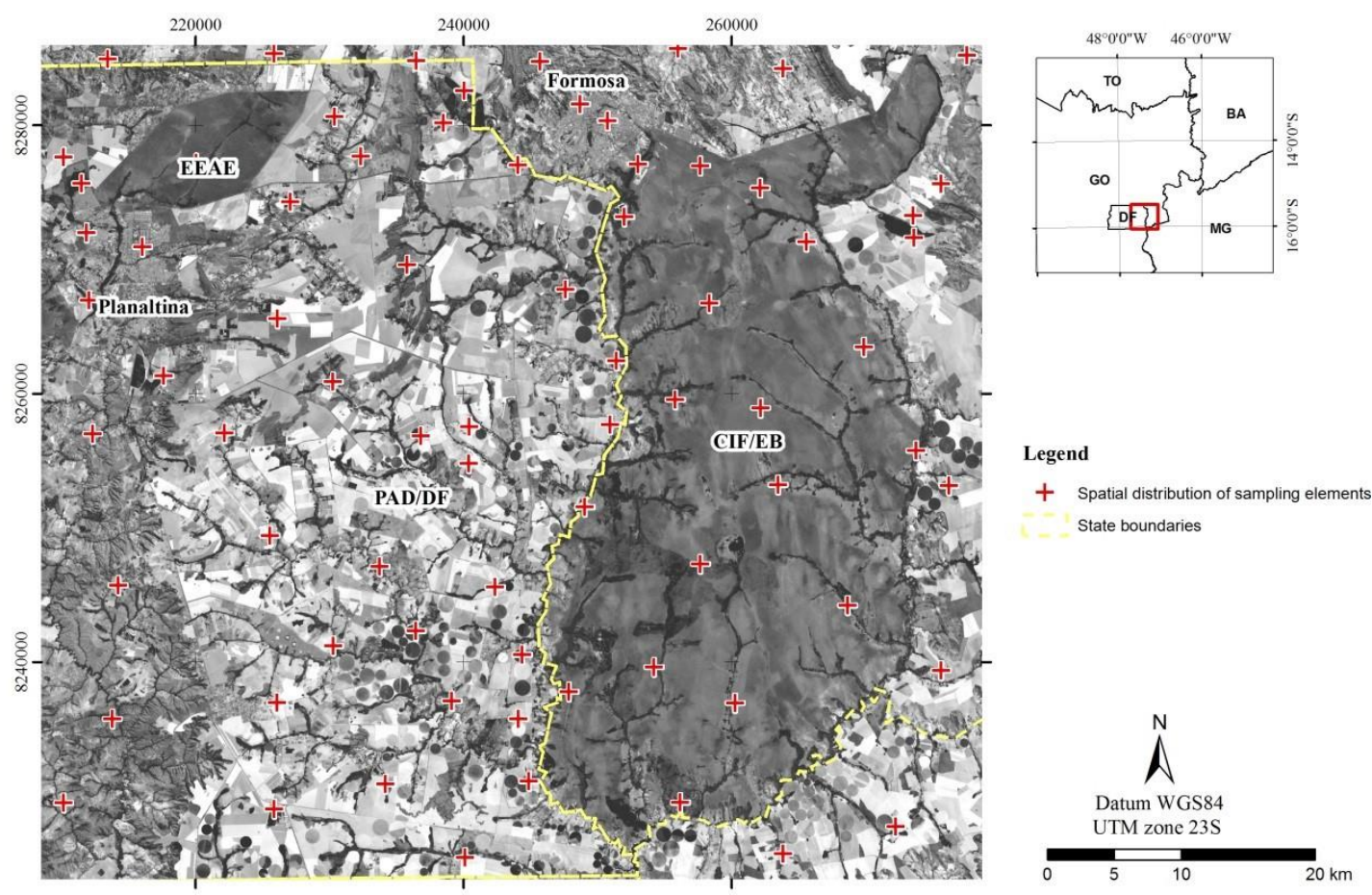

Figura 1. Mapa de localização da área de estudo com a banda 11 do sensor Sentinel2 demonstrando os elementos amostrais utilizados no trabalho. Na área abrange os municípios de Formosa (GO) e Planaltina (DF) e nela ocorrem o Programa de Assentamento Dirigido do Distrito Federal (PAD / DF), a Estação Ecológica de Águas Emendadas (EEAE) e o Campo de Instrução Formosa (CIF / EB).

Figure 1. Location map of the study area with band 11 of the Sentinel2 sensor demonstrating the sample elements used in the work (Red Crosses). It is composed of the Directed Settlement Program of the Federal District (PAD / DF), the Ecological Watershed Station (EEAE), the Formosa Instruction Field (CIF / EB) and the cities of Formosa (GO) and Planaltina (DF).

The definition of the classes in the areas with natural cover followed the classification proposed by Ribeiro and Walter (2008) and the phytophysiognomies were grouped in three main formations: forest formation, savanna formation and field formation. The forest formation included the forest gallerys along the water paths, dry forest and the cerradão ("high Cerrado"), also known as savanna woodland with an almost closed canopy (12-15 m tree height). The savanna formation was composed by Cerrado sensu stricto or wooded savanna (>15\% tree cover, frequently 20-30\%), the most extensive savanna type in Brazil, makes up open Cerrado with a relatively open cover and dense Cerrado with a denser cover. In the field formations, are divided into: Campo limpo or open savanna (2-15\% canopy cover); Campo sujo or scrubland, open savanna with

FLORESTA, Curitiba, PR, v. 50, n. 3, p. 1430 - 1438, jul/set 2020.

Silva, J. F. et.al.

ISSN eletrônico 1982-4688

DOI: $10.5380 /$ rf.v50 i3. 59747 
scattered trees $(<2 \mathrm{~m})$ or shrubs with $<5 \%$ canopy cover (Figure 2). Figure 2 shows the response images of 8 class selected.

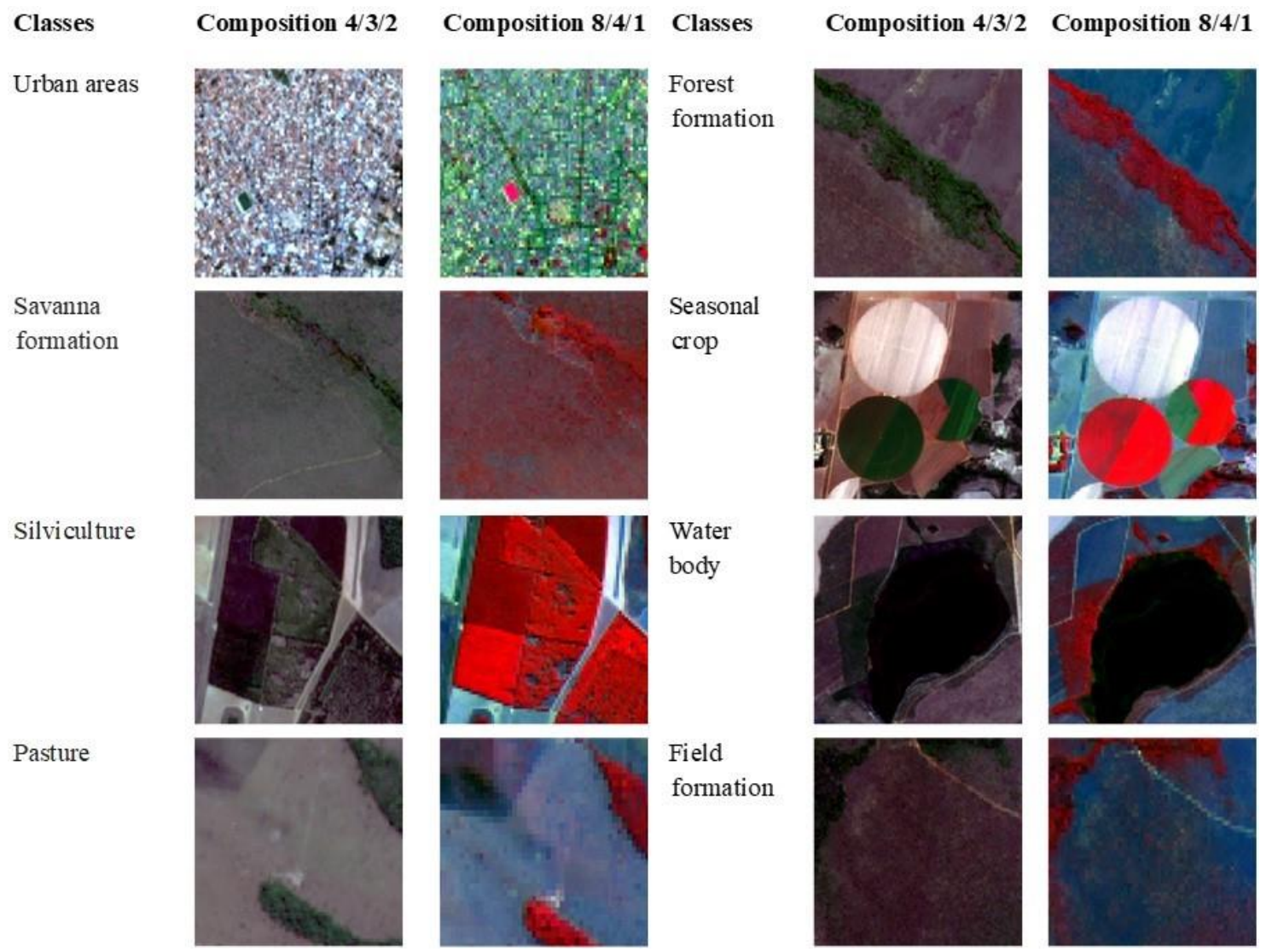

Figura 2. Chave para interpretação de classes de treinamento do classificador. Os fragmentos demonstrados estão na composição RGB 4/3/2 e 8/4/1.

Figure 2. Key to interpretation from each class to train the classifier. The sampled patches are shown in the composition RGB 4/3/2 and 8/4/1.

Within the polygon of study, the seasonal crop class presents irrigated pivots with growing planting, plots where the harvest already occurred and probably remains of organic matter of the crop, and plots with exposed soil. Due to the very distinct spectral behavior of these occupations, it was necessary to divide the training samples of this class into 3 different groups. Each group set up a training sample independent of the others. This was made necessary because the artificial neural network training process would not be successful with a single sample containing so different spectral responses for the same class. Thus, the training samples represent 11 different types of occupations, 3 which represent the same class of land use, named seasonal crop. After processing the classification, the Combine classes tool of the Envi® 5.3 software was used to group the three types of occupation referring to the temporary culture class.

The final interpretation key of the work area resulted in eight independent classes of LULC, as shown in Figure 3. The samples collected for neural network training had approximately 3,000 pixels, since neural networks are more efficient as the larger sample of training.

\section{Neural Network Training}

The next step consisted in the training of the artificial neural network and the production of the classification itself. The "net neural tool" was used from Envi® 5.3 software for classification. The diagram containing the Sentinel-2A satellite data that were used in this work, as well as the artificial neural network (ANN) scheme, the result of the maximum likelihood can be observed in Figure 3.

The ANN used was of the feed forward type with 3 layers, allied to the backpropagation training algorithm. Its architecture consists of an input layer, a hidden layer and an output layer. ANNs with this topology operate with one-way flow of data from the input to the output layer. One characteristic of ANNs is the

FLORESTA, Curitiba, PR, v. 50, n. 3, p. 1430 - 1438, jul/set 2020.

Silva, J. F. et.al.

ISSN eletrônico 1982-4688

DOI: $10.5380 /$ rf.v50 i3. 59747 
possibility of using other data for classification and not only the spectral bands. The data can be derived from the bands or information of another nature (BENEDIKTSSON et al., 1990). This work integrated the NDVI into of the classification.

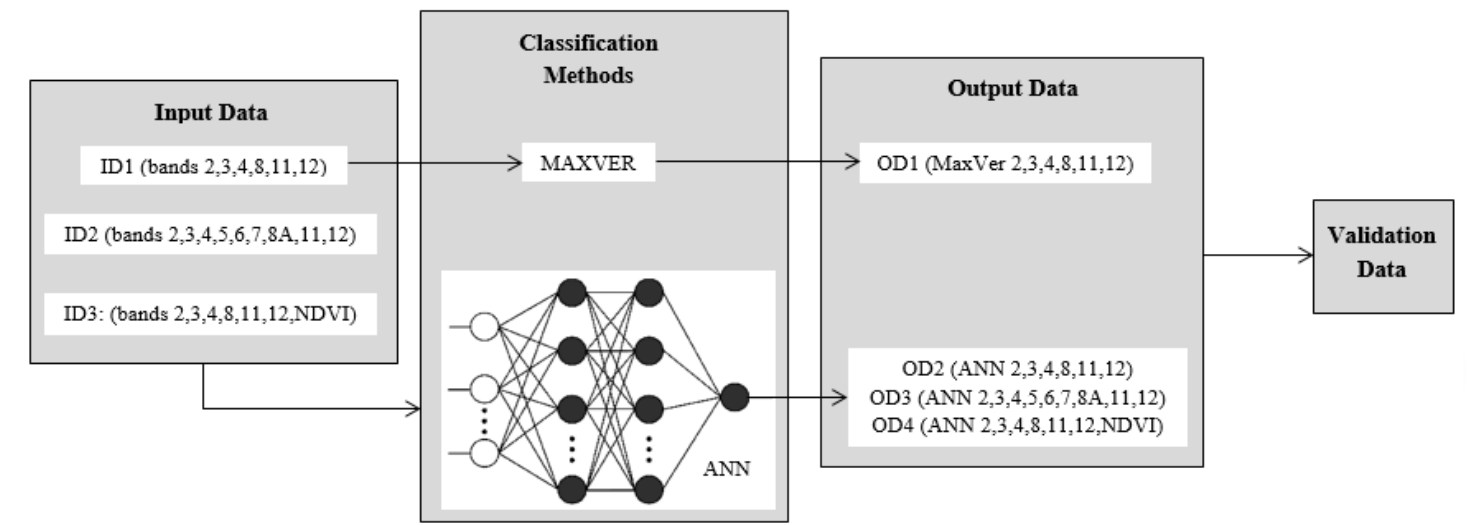

Figura 3. Fluxo metodológico, entrada de dados, métodos de classificação (rede neural artificial e máxima verossimilhança), saída de dados e validação.

Figure 3. Methodological flow, input data, classification methods (MAXVER and ANN), output data and validation.

In total, 32 versions of the classification were generated until the optimal ANN configuration was reached. Different combinations of bands were performed. Most of the classifications were produced with bands 2 Key to interpretation from each class to train the classifier. The sampled patches are shown in the composition RGB 4/3/2 and 8/4/1., 3, 4, 8, 11, 12, called ID1. A version was produced using instead of band 8 bands 5, 6, 7 and 8 A, called ID 2. Another version was created by adding the NDVI together with the bands 2, 3, 4, 8, 11 and 12 , to verify possible improvement in the quality of the mapping with the inclusion of this parameter, this input data was called ID3. The classification results were called OD2, OD3 and OD4, as shown in figure 3.

Using the Maximum Likelihood tool of the Envi® 5.3 software the classification was produced and compared to the classification generated by the neural network. This evaluation was called OD1 (VENKATESH; RAJA, 2003).

After the classification, a generalization process was applied using the Envi® 5.3 Classification Aggregation tool. Groupings with less than 25 pixels were incorporated into the adjacent class of larger area.

\section{Evaluation of the accuracy of classifications}

The accuracy of the classification was measured with the support of the confusion matrix and accuracy index derived from it. This has been the standard method for estimating the thematic accuracy of maps of use/cover. An confusion matrix provides not only a detailed assessment of the agreement between the sampled reference data and the classification results at specific locations, but also a complete description of misclassifications registered to each category (STEHMAN, 1997).

For the generation of the matrix, 74 sample elements (Figure 1) were selected by the using non-aligned systematic sampling. The elements were randomly distributed in the area through the ET Geo Wizards Sampling tool, a module incorporated into the ArcGIS 10.0® software.

The corresponding reference maps (ground truth) of the 74 sample elements were defined using an aerophotogrammetric survey image carried out by the Government of the Federal District in 2015. The aerial photos have spatial resolution of $25 \mathrm{~cm}$ allowing the identification of each feature present in the selected points. To complement, in the area outside the DF were used to identify images of the RapidEye satellite with spatial resolution of $5 \mathrm{~m}$.

Most of the classifications produced by the neural network were evaluated with support from the confusion matrix. Kappa coefficient (Kappa), user accuracy (commission error) and producer accuracy (omission error) were derived from confusion matrix. In order to test the significance of the difference between the calculated indices, several authors cite the application of the $\mathrm{Z}$ test (ARRUDA et al., 2013). This test allows the verification of the significance of only one index or the difference between two indexes. 


\section{RESULTS}

In the ANN training stage, 32 different combinations of parameters were tested and the best result was obtained in the 26th attempt, using 2,000 iterations and 0.2 training rate.

Table 2 shows Kappa coefficient, variance and Z-test to verify the statistical significance of the results obtained in the classifications using ANN with the three different compositions OD2 (bands 2,3,4,8,11,12), OD3 (bands 2,3,4,5,6,7,8A,11,12), OD4 (bands 2,3,4,8,11,12, NDVI) and in the classification using the algorithm of Maximum Likelihood OD1 $(2,3,4,8,11,12)$. The values of the Z-Test were organized in Table 1 , whose main diagonal corresponds to the result of Test $\mathrm{Z}$ for a single Kappa coefficient and the other values show the result of the correlation between two indices (AMORIM et al., 2016). All tests presented the same performance class, considered very good, according to Congalton and Green (1999). However, it was found that there was no significant (NS) statistical difference between the classifiers used and also between the different compositions used.

Tabela 1. Índice Kappa, variância e teste $Z$ de significância das classificações realizadas.

Table 1. Kappa index, variance and $\mathrm{Z}$ test of significance of the performed classifications.

\begin{tabular}{|c|c|c|c|c|}
\hline & $\begin{array}{c}\text { OD3 } \\
\text { (ANN 2,3,4,5, } \\
\mathbf{6 , 7 , 8 A , 1 1 , 1 2} \\
\end{array}$ & $\begin{array}{c}\text { OD1 } \\
\text { (MaxVer 2,3, } \\
4,8,11,12) \\
\end{array}$ & $\begin{array}{c}\text { OD2 } \\
(A N N 2,3,4 \\
8,11,12) \\
\end{array}$ & $\begin{array}{c}\text { OD4 } \\
(A N N \text { 2,3,4,8, } \\
11,12, \text { NDVI) }\end{array}$ \\
\hline Kappa & 0.70 & 0.73 & 0.75 & 0.77 \\
\hline Variance & 0.0183 & 0.0013 & 0.0016 & 0.0014 \\
\hline OD3 (ANN 2,3,4,5, 6,7,8A,11,12 & 5,170 & & & \\
\hline OD1 (MaxVer 2,3, 4,8,11,12) & $0.68 \mathrm{NS}$ & 20.24 & & \\
\hline OD2 (ANN 2,3,4, 8,11,12) & $0.86 \mathrm{NS}$ & $0.47 \mathrm{NS}$ & 18.75 & \\
\hline OD4 (ANN 2,3,4,8, 11,12, NDVI) & $1.25 \mathrm{NS}$ & $1.31 \mathrm{NS}$ & $0.36 \mathrm{NS}$ & 20.57 \\
\hline
\end{tabular}

Statistical $\mathrm{Z}=1.96$ : significant at $95 \%$ probability.

Table 3 shows that the classification OD2 using band 8, which has a better spatial resolution, a Kappa coefficient of 0.75 was obtained. These results are a little higher, when compared to the classification using band 8A (OD3), however, this difference was not statistically significant. According to Immitzer (2016), bands 5, 6, 7 and $8 \mathrm{~A}$ of the Sentinel-2 satellite show a better response in the differentiation of forest species, due to the detailing capacity of the spectral responses in the near infrared band. In the study area, forest types have not been defined in detail, therefore, such a condition can elucidate the reason for the accuracy not having a relevant increase. It is noteworthy that both classifications used the same training and validation samples, as well as the same neural network configuration.

Tabela 2: Acurácia das classificações utilizando rede neural (ANN) (OD2) e Máxima Verossimilhança.(MaxVer) (OD1)

Table 2: Accuracy of the classifications using artificial neural network (ANN) (OD2) and Maximum Likelihood (MaxVer) (OD1).

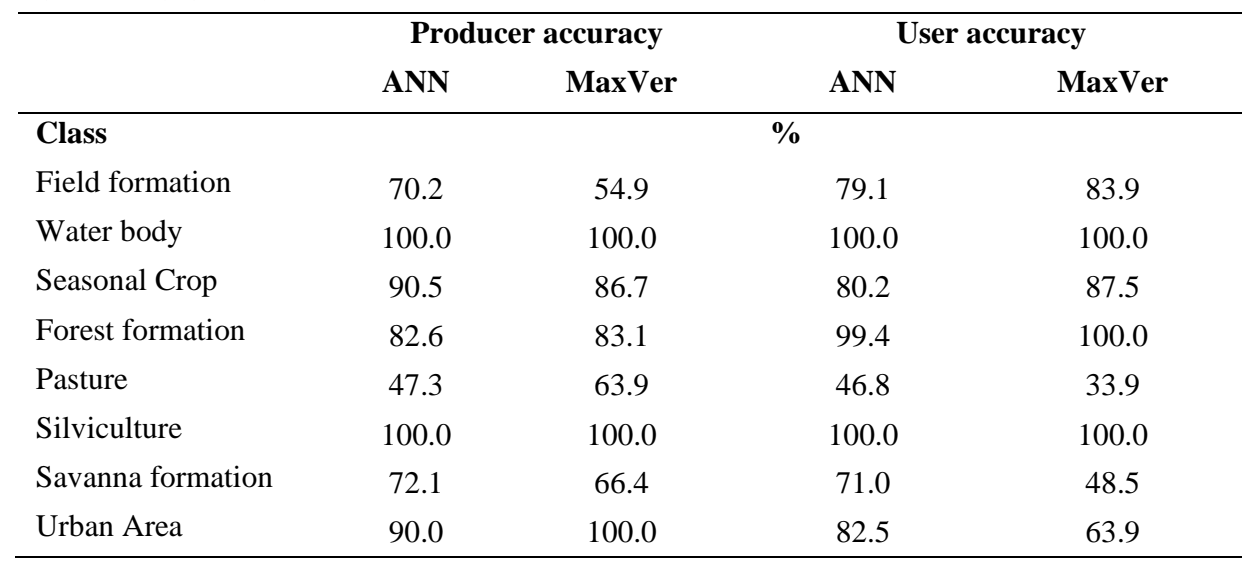

When comparing the absolute values, of the accuracies obtained through the MaxVer classifier (OD1) and the neural network (OD2), which have the same bands configuration, the ANN presented higher values. The

FLORESTA, Curitiba, PR, v. 50, n. 3, p. 1430 - 1438, jul/set 2020.

Silva, J. F. et.al.

ISSN eletrônico 1982-4688

DOI: 10.5380/rf.v50 i3. 59747 
Kappa coefficient obtained by ANN reached 0.75. The same coefficient resulting from the MaxVer classification were 0.73. Hepner et al. (1990) used Landsat TM images and neural networks to classify field coverage and concluded that the neural network approach was more efficient than traditional statistical classification. Their results were compared with those obtained by the MaxVer classifier, and obtained an overall accuracy of $93.1 \%$ versus $89.7 \%$ obtained with MaxVer. The best results were achieved using input data ID3 with ANN classifier (OD4) with kappa of 0.77 .

The inclusion of NDVI (Normalized Difference Vegetation Index) in the artificial neural network together with the spectral bands (OD4) provided an improvement in classification, probably this index enhanced the differences between vegetation classes as field formation, Seasonal Crop, Forest formation, Pasture and Savanna formation.

Table 2 shows the accuracy of the producer and user in all classes for the two classification methods. Evaluating individually the accuracy of the classes it was possible to better detail the performance of each classifier. In both classifiers tested, the silviculture and water body classes were $100 \%$ correctly classified. The second best performance of the neural network was in the urban area class that reached $90 \%$ for the accuracy. For the MaxVer classifier, the second best performance occurred in the seasonal crop training class, the producer's accuracy was $83 \%$. Figure 4 shows the map of LULC of the study area obtained through the classifier and composition that obtained the best performance, in which ANN was used with bands 2, 3, 4, 8, 11 and 12 and also the NDVI (OD4).
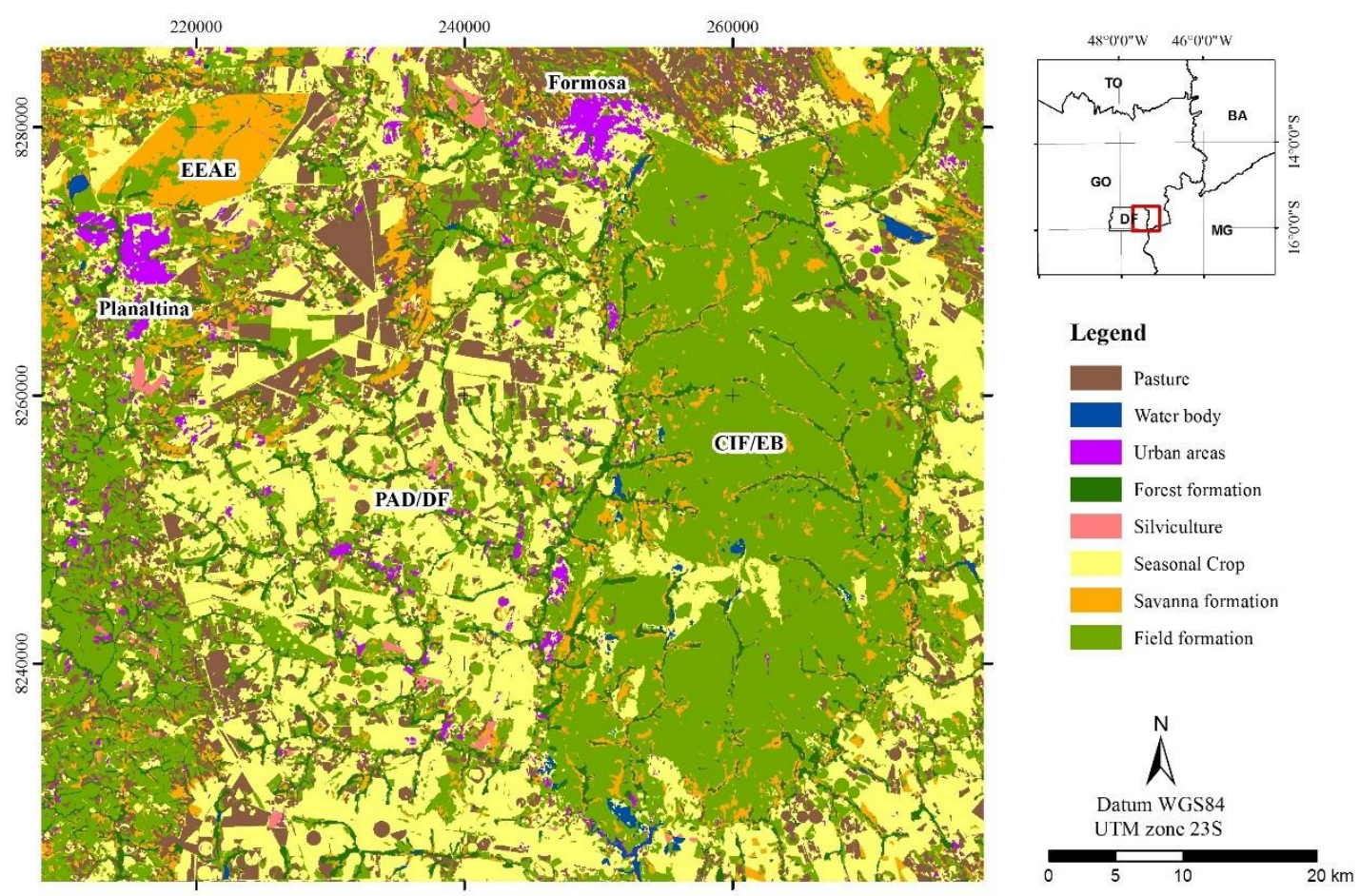

Figura 4. Mapa de uso e cobertura da terra da área de estudo usando o classificador da rede neural artificial. Figure 4. Map of LULC mapping of the study area using the artificial neural network classifier.

\section{DISCUSSION}

With regard to land use and cover, the pressure of agriculture in the region is evident. Over the past decades, agriculture has been the major anthropic and was responsible for drastic landscape transformation on Cerrado (GRECCHI, 2014). The Campo de Instrução de Formosa identified on the map as CIF/ EB realize an important role of redution of deforestation in the region. Despite not being a Conservation Unit, it has played an important role in biodiversity conservation. It is evident that the Programa de Assentamento Dirigido do Distrito Federal (PAD / DF) needs the implementation of practical soil conservation measures to maintain soil fertility and quality in agricultural production.

About classifier efficiency the attempt to optimize the classifier ANN with different band compositions has yielded positive results, in which the best composition was resulted from bands 2,3,4,8,11,12 (called OD2)

FLORESTA, Curitiba, PR, v. 50, n. 3, p. 1430 - 1438, jul/set 2020.

Silva, J. F. et.al.

ISSN eletrônico 1982-4688

DOI: $10.5380 /$ rf.v50 i3. 59747 
despite originally presenting different spatial resolutions. The inclusion of NDVI (Normalized Difference Vegetation Index) in this composition (OD4) provided an improvement in classification. In conjunction with the use of the classifier, the accumulated reflectance technique could be tested, as in the work of Grande et al. (2016) in an attempt to improve the classifier's performance.

The ANN presented worse performance in the pasture class with producer accuracy of $47 \%$, whose the more confusion was with the seasonal crop class. Already in the classification using MaxVer, the lowest accuracy of the product was found in the field formation class and the hit rate of the classifier was $55 \%$. The confusion occurred mainly with the pasture class and to a lesser extent with the seasonal crop class. This was expected, since in both classes, in the drought season, they had significant presence of exposed soil and dry matter (SANO et al., 2009).In both methods, the pasture class was a challenge for the classifiers. The difficulty arose in the attempt to separate natural areas, such as the field formations and planted pastures, because the spectral responses of both classes have characteristics that make them very similar. Sano et al. (2009) also encountered the same difficulty and required ancillary data from the Agricultural Census to estimate natural and cultivated areas. Thus the results showed that pasture class of the cerrado makes it considerably more difficult to map LULC, even with the use of Sentinel-2A satellite data. It is suggested to test other tools and classification methods such as Google Earth Engine (GEE) and machine learning algorithms to be tested from different times for Cerrado monitoring

When analyzing Table 2, it was also verified that the lowest thematic accuracy presented in the thematic classes: field formation, seasonal crop and savanna formation. This classes have a low tree stratum, and may have a spectral response similar to that of field, temporal and rural vegetation (NUNES; ROIG, 2015). This position is supported by the fact that a part of CIF/EB (Training Area of the 6th Group of Multiple Rocket Launchers - Astro II) was classified as seasonal crop, when really is composed by natural vegetation cover formed by wooded cerrado, open savanna, scrubland and forest gallery.

\section{CONCLUSION}

- The Sentinel-2A image used in this study showed good potential for LULC mapping in the Cerrado, reaching levels of accuracy compatible with other sensors widely used in this type of work. Regardless of the band compositions, as well as the different classifiers used, all the results were shown with a performance considered in the very good range. This sensor offers optimum spatial, spectral and temporal resolution, which represents an evolution in relation to other sensors that offer freely accessible data.

- All classifiers and the different combinations of bands showed very good performance. There has been much growth in the advancements in technology and the availability of remote sensing image. But image classification techniques should be taken into consideration as well. The object-based classification has been used in some papers and it has offered quality products.

- More studies are needed to better define the bands and classifiers for the mapping of use and occupation in the Cerrado Biome, in order to guide the best use of Sentinel-2A satellite data.

\section{REFERENCES}

AMORIM, R. M.; ALBARICI, F.L.; PINO, M. A. I. T. Mapa digital do escoamento superficial por meio de imagens de sensor remoto na sub-bacia do Rio Moji Guaçu - MG. Revista Brasileira de Geografia Física, 9(3), pp. 881-896, 2016.

ARRUDA, G. P.; DEMATTÊ, J. A. M.; CHAGAS, C. S. Mapeamento digital de solos por redes neurais artificiais com base na relação solo-paisagem. Revista Brasileira de Ciência do Solo, 37, pp.327-338, 2013.

BENEDIKTSSON, J. A.; SWAIN, P. H.; ERSOY, O. K. Neural Network Approaches Versus Statistical Methods in Classification of Multisource Remote Sensing Data. IEEE Transactions on Geoscience and Remote Sensing, 28(4), pp. 540-552, 1990.

BRANNSTROM, C.; JEPSON, W.; FILIPPI, A. M.; REDO, D.; XU, Z.; GANESH, S. Land change in the Brazilian Savanna (Cerrado), 1986-2002: comparative analysis and implications for land-use policy. Land Use Policy, 25(4), pp. 579-595, 2008.

CONGALTON, R. G.; AND GREEN, K. Assessing the accuracy of remotely sensed data: Principles and practices. New York: Lewis Publishers, 137p., 1999.

FLORESTA, Curitiba, PR, v. 50, n. 3, p. 1430 - 1438, jul/set 2020.

Silva, J. F. et.al.

ISSN eletrônico 1982-4688

DOI: 10.5380/rf.v50 i3. 59747 
DENG, Z. et al. Land use/land cover classification using time series Landsat 8 images in a heavily urbanized area. Advances in Space Research, v. 63, n. 7, p. 2144-2154, 2019.

DU, Y.; ZHANG, Y.; LING, F.; WANG, Q.; LI, W.; LI, X. Water bodies mapping from Sentinel-2 imagery with Modified Normalized Difference Water Index at 10-m spatial resolution produced by sharpening the SWIR band. Remote Sensing, 8, pp. 354-373, 2016.

ESA - European Space Agency. Sentinel-2 user handbook. 1.ed. Darmstadt: ESA, p. 64, 2015.

GRANDE, T.O.; ALMEIDA, T.; CICERELLI, R.E. Classificação orientada a objeto em associação às ferramentas reflectância acumulada e mineração de dados. Pesquisa Agropecuária Brasileira, 51(12), pp.19831991,2016

GRECCHI, R. C.; GWYN, Q. H. J.; BÉNIÉ, G. B.; FORMAGGIO, A. R.; FAHL, F. C. Land use and land cover changes in the Brazilian Cerrado: A multidisciplinary approach to assess the impacts of agricultural expansion. Applied Geography, 55, pp. 300-312, 2014.

HEYDARI, S. S.; MOUNTRAKIS, G. Meta-analysis of deep neural networks in remote sensing: A comparative study of mono-temporal classification to support vector machines. ISPRS Journal of Photogrammetry and Remote Sensing, v. 152, p. 192-210, 2019.

HEPNER, G. F.; LOGAN, T.; RITTER, N.; BRYANT, N. Artificial neural network classification using a minimal training set: comparison to conventional supervised classification. Photogrammetric Engineering and Remote Sensing, 56, pp.469-473., 1990.

IBGE - Instituto Brasileiro de Geografia e Estatística. Manual técnico de uso da terra. 3.ed. Rio de Janeiro: IBGE, 171p., 2013.

IMMITZER, M.; VUOLO, F.; ATZBERGER, C. First experience with Sentinel-2 data for crop and tree species classifications in central Europe. Remote sensing, 8(3), p.166., 2016.

MANDANICI, E.; AND BITELLI, G. 2016. Preliminary Comparison of Sentinel-2 and Landsat 8 Imagery for a Combined Use. Remote sensing. 8(12), pp. 1014, 2016.

NUNES, J. F.; ROIG, H. L. Análise e mapeamento do uso e ocupação do solo da bacia do Alto do Descoberto, $\mathrm{DF} / \mathrm{GO}$, por meio de classificação automática baseada em regras e lógica nebulosa. Revista Árvore [online], 39(1), pp.25-36, 2015.

RIBEIRO, J. F.; WALTER, B. M. T. As principais fitofisionomias do Bioma Cerrado. Cerrado: ambiente e flora. Embrapa Cerrados, Planaltina. p. 151-212, 2008.

RICHARDS, J. A. Supervised classification techniques. In: Richards, J. A. Remote sensing digital image analysis: an introduction. 5 ed. Berlin: Spinger-Verlag, pp. 247-318, 2013.

SANO, E. E. et al. Land use dynamics in the Brazilian Cerrado in the period from 2002 to 2013. Pesquisa Agropecuária Brasileira, v. 54, 2019a.

SANO, E. E. et al. Cerrado ecoregions: A spatial framework to assess and prioritize Brazilian savanna environmental diversity for conservation. Journal of environmental management, v. 232, p. 818-828, 2019 b.

SANO, E. E.; ROSA, R.; BRITO, J. L. S.; FERREIRA, L. G. Land cover mapping of the tropical savanna region in Brazil. Environmental Monitoring and Assessment, 166(1), pp.113-124, 2009.

SOUZA MENDES, F. et al. Optical and SAR remote sensing synergism for mapping vegetation types in the endangered Cerrado/Amazon ecotone of Nova Mutum-Mato Grosso. Remote Sensing, v. 11, n. 10, p. 1161, 2019.

STEHMAN, S.V. Selecting and interpreting measures of thematic classification accuracy, Remote Sensing of Environment, 62 (11), pp. 77-89, 1997.

SCHWIEDER, M.; LEITÃO, P. J.; DA CUNHA BUSTAMANTE, M. M.; FERREIRA, L. G.; RABE, A.; HOSTERT, P. Mapping Brazilian savanna vegetation gradients with Landsat time series. International journal of applied earth observation and geoinformation, 52, p. 361-370, 2016.

VENKATESH, Y. V.; RAJA, S. On the classification of multispectral satellite images using the multilayer perceptron. Pattern Recognition, 36, pp.2161 - 2175. 2003.

FLORESTA, Curitiba, PR, v. 50, n. 3, p. 1430 - 1438, jul/set 2020.

Silva, J. F. et.al.

ISSN eletrônico 1982-4688

DOI: 10.5380/rf.v50 i3. 59747 